\title{
Examining Post-Graduation Career Plans of International Doctoral Students in the United States
}

\author{
Osasohan Agbonlahor Sylvia L. Mendez Andrea Bingham \\ University of Colorado Colorado Springs \\ 1420 Austin Bluffs Pkwy | Colorado Springs, CO 80918 \\ E-mail: oagbonla@uccs.edu
}

\begin{abstract}
Understanding the career trajectories of $\mathrm{PhD}$ recipients is an important topic of investigation, particularly for foreign students who may work in a different country from where their degree was obtained. In the United States, approximately $70 \%$ of $\mathrm{PhD}$ recipients enter employment in industry, government, or academia upon graduation, while nearly $30 \%$ seek further training through a postdoctoral appointment (NCSES, 2019). Over the last decade, post-doctoral appointments have become a more popular option for those who are seeking to transition into academia. The purpose of this research is to examine whether demographic variables and sources of financial support received during doctoral education influences the career decisions of international doctoral students in the United States. A multinomial logistic model and predicted probabilities were employed to examine relationships between primary sources of financial support and choices of faculty versus non-faculty positions faculty, postdoctoral training, and other employment categories. The post-graduation location has the most significant and robust impact on career plans, with those who will remain in the United States being more likely to choose to work in academia. Plots of predicted probabilities show that research and teaching assistantships have greater influence on those from lower-income countries in choosing faculty positions.
\end{abstract}

Keywords: Doctoral students, international students, career plans

DOI: $10.7176 / \mathrm{JEP} / 12-20-03$

Publication date:July $31^{\text {st }} 2021$

\section{Introduction}

Traditionally, doctoral programs have trained students primarily for a career in academia (Agarwal \& Sonka, 2010). Non-academic occupations may have similar norms but differ in terms of the work and utilization of the competences acquired through doctoral education (Thune, 2009). The literature in this area has suggested the career preferences of doctorate holders are formed to a certain degree during graduate work, and different factors affect the chosen career path for different fields. Practical experiences during doctoral work (Mangematin et al., 2000) and desire for stable employment (Cruz-Castro \& Sanz-Menendez, 2005) tend to affect the choice to work in industry.

Doctoral degree holders who have worked with non-academic objectives and have collaborated with industry through internships during their studies are more likely to be interested in careers outside academia (Gemme \& Gingras, 2012; Thune, 2009). Roach and Sauermann (2010) found science and engineering students who prefer industrial employment possess a weaker "taste for science," a greater concern for salary and access to resources, as well as a stronger interest in downstream work compared to $\mathrm{PhD}$ students who prefer academic employment. This evidence suggest that $\mathrm{PhD}$ students self-select into employment sectors and, although the decision is made before graduation, these individuals do not consider the role of supply and demand on actual choices of employment.

Bloch et al. (2015) used data from the 2006 Careers of Doctorate Holders (CDH) survey for Denmark to analyze the effect of personal preferences and labor market factors on choice of employment sector. The authors sought to examine the extent to which push-and-pull factors influenced employment choices of doctorate holders, as well as the personal preferences that were most important for this choice. Bloch et al. employed a multinomial logit analysis in which the higher education sector was the reference group. Results indicated preferences for research determined employment in institutions of higher education, business sector $\mathrm{R} \& \mathrm{D}$, and to a somewhat lesser extent, public sector R\&D. Academic discipline generally has affected the decision to embark on postdoctoral fellowships, with those in the sciences tending to accept more fellowships than in other fields. In addition, postdoctoral fellowships encompass significant earning implications. Pederson (2015) found personal characteristics, such as age, gender, having children, and scholarly field, are important in decisions for employment. Mobility both across and within sectors was shown to decrease with age. Gibbs et al. (2014) examined career interest patterns based on social identity (race/ethnicity, gender, and their intersection) and found first-author publication rate, faculty support, research self-efficacy, and graduate research experiences were responsible for differences in career pathway interest between social identity groups.

Studies on doctoral education have researched time-to-degree (Agbonlahor, 2019; Ehrenberg \& Marvos, 1995; Dongbin \& Otts, 2010, Ferrer de Valero, 2001), race (Ellis, 2001), program characteristics (Ehrenberg et 
al., 2007), postdoctoral researchers (Gluck et al., 1987), mentorship (Ku et al., 2008), gender differences (Patrick, Borego \& Riegle-Crumb, 2021) and labor market destination (Agbonlahor \& Ampaw, 2021; Ugwu \& AdamutiTrache, 2017). For doctoral students who study in a country different from their home, the factors that impact domestic student choices may be different from theirs, particularly because they must deal with two economies that impact their financial sources and career sector choices. This study examines the effects of type of funding on career choices of international doctoral recipients using data from the SED and classification of students' home countries to address the following research questions:

1. Are different sources of financial support related to the career sector choices of international doctoral students?

2. Does the relationship between financial support and post-graduation plans of international doctoral students differ by the student's home country's region and income classification?

\section{Theoretical Framework}

Human capital theory can explain the decision process of international doctoral students. Economists and higher education researchers have used the theory to explain the way in which and the reasons individuals decide to invest in higher education (Becker, 1964). The conceptual framework assumes opportunity costs affect student decisions that impact career sector choices. International doctoral students choose to pursue foreign higher education in anticipation of the expected benefits from the investment, which may be intrinsic and/or extrinsic. Extrinsic benefits consist of the future earnings expected by individuals as they use their education in economic activity (Becker, 1964). The H-1B constraints and immigration laws may affect the career sector choices of international students depending upon whether they prefer to remain in the US or return to their home country. The type of funding received during the doctoral years may influence the category of work performed (research, teaching, etc.), which ultimately impacts career decisions. This is because certain types of funding impact doctoral students' mentoring and socialization opportunities. For example, students who received research and/or teaching assistantships will work more closely with faculty members and thus, be more prepared for future faculty roles. Doctoral and postdoctoral students who work more closely with faculty members as Graduate Research Assistants (GRAs) obtain more preparation for academic positions. On the other hand, students who relied on internships or government funding will experience less socialization with faculty and may be more likely to choose non-academic positions after graduation. This may differ by discipline, as well as by type of institution and the degree to which doctoral students are integrated within the department. Researchers have studied the different stages of the socialization process, which comprises anticipatory socialization, occupational entry and induction, and the beginning stage of the process of accepting a faculty position (Corcoran \& Clark, 1984). Austin and McDaniel (2006) described graduate education functions as a socialization process for students as they prepare for future faculty roles. In this sense, doctoral and postdoctoral experiences serve as periods of anticipatory socialization. Hence, socialization and graduate school experiences in certain funding options have an impact in shaping the desires and choice of career sector upon graduation.

\section{Methodology}

In order to clarify the relationship between financial sources and the post-graduation plans of international doctoral students, two data sets were incorporated: Survey of Earned Doctorates from the National Science Foundation and the Integrated Postsecondary Education Data System (IPEDS) from the National Center for Education Statistics (NCES).

\subsection{Variables}

The dependent variable, Post-Graduation Plans, indicated whether students stated they would be working as a faculty member in an institution of higher education, as a postdoctoral researcher, or working for an "Other" type of employer after graduation. The independent variables were categorized into five groups: demographic, academic, financial, external responsibilities, and economic conditions. These demographic variables included gender, age, and first-generation status. The external responsibilities consisted of marital status and dependents. Financial aid variables included loans, assistantships, U.S.-awarded grants, and fellowships and scholarships from the home country.

Institutional-level variables included the Carnegie classification (research institutions R1/R2 and doctoral institutions). The academic variables were coded into seven categories: Biological Sciences, Engineering, Physical Sciences, Social Sciences, Humanities, Education, and Business. Home country region classification followed the World Bank (2017) categorization of seven broad categories: Europe and Central Asia, East Asia and the Pacific, Latin America and the Caribbean, North America, South Asia, and Sub-Saharan Africa. Home country income classification is based on the World Bank's four categories - High income, Upper-middleincome, Lower-middle-income, and Low-income. 


\subsection{Analysis}

The multinomial logit model was expected to regress the dependent variable of Post-Graduation Plans on the key independent variable of Source of Support and other covariates. Multinomial logit estimation is a variant of the loglinear model and is appropriate when the dependent variable represents a set of discrete categories (Garson, 2016). Because the dependent variable in this study was categorical, multinomial logit models estimated the probability of occurrence in each category (plans to be a faculty member, plans to be a postdoctoral researcher) relative to one base category (plans to obtain a job outside of academia).

\section{Results}

Table 1 presents the descriptive statistics for the categorical variables. The initial sample consisted of $63 \%$ men and $37 \%$ women $(\mathrm{N}=50,000)$. Students from East Asia comprised $47 \%$ of the sample and based on the World Bank classifications, High-income countries accounted for $25 \%$ and Upper-middle-income countries $51 \%$ of the total population. Forty seven percent of the students were supported by research assistantships, $20 \%$ by fellowships, $23 \%$ by teaching assistantships, and $4 \%$ by foreign government/entities.

\section{TABLE 1.}

DESCRITPTIVE STATISTICS FOR DEPENDENT AND INDEPENDENT VARIABLES

\begin{tabular}{|c|c|c|}
\hline Variable & & Mean \\
\hline \multicolumn{3}{|c|}{ Dependent Variable } \\
\hline \multicolumn{3}{|l|}{ Post-Graduation Plans } \\
\hline Faculty & & 37.66 \\
\hline Postdoctoral researcher & & 53.65 \\
\hline Other employment & & 8.64 \\
\hline \multicolumn{3}{|c|}{ Independent Variables } \\
\hline Post-graduation location: US & & 77.1 \\
\hline Age & & 32.22 \\
\hline Gender: Female & & 37.2 \\
\hline \multicolumn{3}{|l|}{ Parents Education } \\
\hline \multicolumn{3}{|l|}{ First generation } \\
\hline \multicolumn{3}{|l|}{ Bachelor's degree or higher } \\
\hline \multicolumn{3}{|l|}{ Region } \\
\hline Europe and Central Asia & & 12.9 \\
\hline East Asia and Pacific & & 46.7 \\
\hline Latin America and the Caribbean & & 7.2 \\
\hline Middle East and North Africa & & 8.8 \\
\hline North America & & 3.1 \\
\hline South Asia & & 17.9 \\
\hline Sub-Saharan Africa & & 3.2 \\
\hline \multicolumn{3}{|l|}{ Economy } \\
\hline High income & & 24.7 \\
\hline Upper-middle income & & 50.8 \\
\hline Lower-middle income & & 22.1 \\
\hline Low-income & & 2.4 \\
\hline \multicolumn{3}{|l|}{ Prior Academic Experience } \\
\hline U.S Bachelors & & 8.8 \\
\hline U.S Masters & & 59.1 \\
\hline \multicolumn{3}{|l|}{ Academic Disciplines } \\
\hline Biological sciences & & 18.3 \\
\hline Engineering & & 29.3 \\
\hline Physical sciences & & 25.2 \\
\hline Social sciences & & 11.2 \\
\hline Humanities & & 4.6 \\
\hline Education & & 3.5 \\
\hline Business management & & 3.7 \\
\hline Others/Non-classified & & 4.0 \\
\hline \multicolumn{3}{|l|}{ Family/External Responsibilities } \\
\hline Single & & 43.3 \\
\hline Dependents & & 27.9 \\
\hline Married & & 59.37 \\
\hline
\end{tabular}




\begin{tabular}{lc}
\hline Variable & Mean \\
\hline Primary Financial Support & 20.77 \\
Fellowship/grants/scholarships & 46.89 \\
Research assistantship & 22.79 \\
Teaching assistantship & 4.33 \\
Foreign government & 0.49 \\
Loans & 4.72 \\
Others (savings, family internships) & \\
\hline
\end{tabular}

\subsection{Findings for Faculty Plans}

Table 2 presents the results for doctoral student plans to be faculty. Compared with married students, single students $(B=0.038, \rho<0.001)$ were significantly more likely to choose faculty positions. Older students were also more likely to choose faculty positions. On the other hand, doctoral students with dependents $(B=-0.116, \rho$ $<0.001)$ and those who obtained their Bachelors' degree in the United States $(B=-0.306, \rho<0.001)$ were less likely to choose faculty positions. Contrary to a priori expectations, financial support does not play a significant role in the choice of faculty career for foreign students (again, in comparison to the reference group). For faculty positions, the estimated relationships between the different types of assistantships and post-graduation plans were statistically insignificant except for those supported by foreign governments, who had reduced odds of planning to become faculty members. Researchers (Fernandez, 2019) have found that teaching assistantships significantly increase the odds of wanting to become a faculty member for domestic students (when both were compared to the reference category), but this research finds no statistical significance for their international counterparts. International students differ greatly from their domestic peers in how they experience sources of support and their perception of the job markets both in the United States and in their home countries. The "Loans" category was not statistically significantly related to post-graduation plans to work as faculty or postdoc after graduation.

Compared to their peers from Europe and Central Asia, students from East Asia, Middle East, and North Africa (MENA), South Asia, and Sub-Saharan Africa had higher odds of planning to become faculty members, although the estimated effect is larger for students from East Asia and the Pacific. Compared with students from Upper-middle-income countries, students from High-income countries were less likely to choose faculty positions. We also find significant field/disciplinary differences in the plans of faculty and postdoc positions. Compared to the reference group, we find students from the Biological Sciences and Engineering were more likely to plan to become faculty members while students of the Physical Sciences had reduced odds. An important finding is the role of the anticipated post-graduation location on career sector choices. This is the most robust variable and accounts for the largest estimated effect across all models. We find that those choosing to work in the United States after graduation have greater odds of planning to become faculty members. Finally, doctoral recipients from research institutions (R1/R2) were more likely to plan for faculty positions.

TABLE 2.

MULTINOMIAL LOGISTIC ESTIMATION TESTING INTERNATIONAL DOCTORAL RECIPIENTS' LIKELIHOOD OF HAVING PLANS TO BE FACULTY, REFERENCE: OTHER EMPLOYMENT.

\begin{tabular}{|c|c|c|c|c|}
\hline \multirow[b]{2}{*}{ Independent Variable } & \multicolumn{2}{|c|}{ By Income } & \multicolumn{2}{|c|}{ By Region } \\
\hline & Coef. & Std. Err. & Coef. & Std. Err. \\
\hline Gender: Female & 0.032 & 0.057 & 0.032 & 0.057 \\
\hline Age & $0.037 * * *$ & 0.007 & $0.035 * *$ & 0.007 \\
\hline Single & $0.038 * * *$ & 0.060 & $0.045 * * *$ & 0.060 \\
\hline Dependents & $-0.116^{* * *}$ & 0.069 & $-0.151 * * *$ & 0.069 \\
\hline Parental education: First generation & -0.029 & 0.056 & -0.008 & 0.057 \\
\hline U.S. Bachelor's degree & $-0.306 * * *$ & 0.108 & $-0.312 * * *$ & 0.108 \\
\hline U.S. Master's degree & 0.079 & 0.056 & 0.705 & 0.056 \\
\hline Doctoral time-to-degree completion & 0.002 & 0.020 & 0.008 & 0.020 \\
\hline Year of doctorate completion & 0.005 & 0.052 & 0.002 & 0.052 \\
\hline Post-graduation location: United States & $2.008 * * *$ & 0.063 & $2.011 * * *$ & 0.054 \\
\hline \multicolumn{5}{|c|}{ Academic Discipline (Reference: Social Sciences) } \\
\hline Biological Sciences & $0.213 * * *$ & 0.091 & $0.411 * * *$ & 0.091 \\
\hline Engineering & $0.352 * * *$ & 0.090 & $0.115 * * *$ & 0.090 \\
\hline Physical Sciences & $-0.429 * * *$ & 0.085 & $-0.437 * * *$ & 0.085 \\
\hline Humanities & -0.243 & 0.124 & -0.195 & 0.125 \\
\hline Education & 0.138 & 0.168 & 0.127 & 0.168 \\
\hline Business Management & -0.232 & 0.281 & -0.257 & 0.281 \\
\hline
\end{tabular}




\begin{tabular}{|c|c|c|c|c|}
\hline \multirow[b]{2}{*}{ Independent Variable } & \multicolumn{2}{|c|}{ By Income } & \multicolumn{2}{|c|}{ By Region } \\
\hline & Coef. & Std. Err. & Coef. & Std. Err. \\
\hline \multicolumn{5}{|l|}{ Financial Support (Reference: Others) } \\
\hline Fellowship/grants/scholarships & -0.108 & 0.147 & -0.145 & 0.147 \\
\hline Research assistantship & 0.585 & 0.148 & 0.591 & 0.148 \\
\hline Teaching assistantship & 0.139 & 0.150 & 0.137 & 0.151 \\
\hline Foreign government & $-0.223 * * *$ & 0.170 & -0.218 & 0.172 \\
\hline Loans & -0.082 & 0.064 & 0.026 & 0.065 \\
\hline Research institutions (Ref: Doctoral institutions) & $0.319 * * *$ & 0.123 & -0.109 & 0.123 \\
\hline \multicolumn{5}{|c|}{ Home Country Classification (Reference: High-Income) } \\
\hline Upper-middle-income & $0.310 * * *$ & 0.067 & - & - \\
\hline Lower-middle-income & -0.183 & 0.068 & - & - \\
\hline Low-income & 0.164 & 0.171 & - & - \\
\hline \multicolumn{5}{|c|}{ Home Country Classification (Reference: Europe and Central Asia) } \\
\hline East Asia and Pacific & - & - & $0.257 * * *$ & 0.082 \\
\hline Latin America and the Caribbean & - & - & -0.055 & 0.112 \\
\hline Middle East and North Africa & - & - & $0.243 * * *$ & 0.109 \\
\hline North America & - & - & $-0.301 * *$ & 0.148 \\
\hline South Asia & - & - & $0.036 * *$ & 0.092 \\
\hline Sub-Saharan Africa & - & - & $0.220 * *$ & 0.161 \\
\hline
\end{tabular}

\subsection{Findings for Postdoctoral Plans}

Table 3 presents the results for plans to pursue a postdoctoral position after graduation. Among sources of support, we found that fellowships, research assistantships, and foreign government funding were negatively related to the odds that doctoral students planned to be post-doctoral researchers after graduation (when compared with the reference category, other employment). Amongst the demographic variables we found that single students $(B=0.197, \rho<0.001)$ were significantly more likely to choose postdoctoral positions. Recipients with a U.S. Master's degree as well those with longer time-to-degree completion were more likely to choose postdoctoral positions. Doctoral recipients from research institutions (R1/R2) were also more likely to plan for faculty positions. In terms of funding, the results are contrary to expectation. We find that students who were funded with a research assistantship $(B=-0.471, \rho<0.001)$ and fellowships $(B=-0.745, \rho<0.001)$ were less likely to pursue postdoctoral positions (compared to the reference group, other employments). The dataset used for this study does not contain information on postdoctoral earnings in these countries. Hence, it is difficult to speculate the reasons and motivations of the students.

For plans of becoming a post-doctoral researcher, students from East Asia and MENA were more likely to choose postdoc positions while students from South Asia had lower odds of choosing post-doc positions (compared to the reference group, other employments). Compared with students from high-income countries, students from upper-middle-income countries, lower-middle-income countries and low-income countries were less likely to pursue a postdoctoral position after graduation. Students from the STEM disciplines (Biological Sciences, Engineering, and Physical Sciences) have reduced odds of planning for post-doctoral research positions while their peers in the Business and Education fields have higher odds of choosing post-doc positions. Just like with choice of faculty positions, we find that those choosing to work in the United States after graduation have greater odds of planning to work postdoctoral positions. 
TABLE 3.

MULTINOMIAL LOGISTIC ESTIMATION TESTING INTERNATIONAL DOCTORAL RECIPIENTS' LIKELIHOOD OF HAVING PLANS TO BE A POST-DOCTORAL RESEARCHER, REFERENCE: OTHER EMPLOYMENT.

\begin{tabular}{|c|c|c|c|c|}
\hline \multirow[b]{2}{*}{ Independent Variable } & \multicolumn{2}{|c|}{ By Income } & \multicolumn{2}{|c|}{ By Region } \\
\hline & Coef. & Std. Err. & Coef. & Std. Err. \\
\hline Gender: Female & -0.033 & 0.056 & -0.021 & 0.056 \\
\hline Age & -0.011 & 0.007 & -0.005 & 0.007 \\
\hline Single & $0.197 * * *$ & 0.058 & $0.199 * * *$ & 0.058 \\
\hline Dependents & -0.357 & 0.067 & $-0.108 * * *$ & 0.068 \\
\hline Parental education: First generation & 0.001 & 0.055 & 0.027 & 0.055 \\
\hline U.S. Bachelor's degree & 0.789 & 0.102 & 0.137 & 0.102 \\
\hline U.S. Master's degree & $0.439 * * *$ & 0.055 & $0.436 * * *$ & 0.055 \\
\hline Doctoral time-to-degree completion & $0.289 * * *$ & 0.019 & 0.036 & 0.019 \\
\hline Year of doctorate completion & 0.050 & 0.051 & 0.049 & 0.051 \\
\hline Post-graduation location & $1.237 * * *$ & 0.058 & $1.261 * * *$ & 0.057 \\
\hline \multicolumn{5}{|l|}{ Academic Discipline (Reference: Social Sciences) } \\
\hline Biological Sciences & $-0.846^{* * *}$ & 0.091 & $-0.827 * * *$ & 0.091 \\
\hline Engineering & $-0.077 * *$ & 0.087 & $-0.567 * * *$ & 0.087 \\
\hline Physical Sciences & $-0.689 * * *$ & 0.082 & $-0.669 * * *$ & 0.081 \\
\hline Humanities & -0.221 & 0.118 & -0.146 & 0.119 \\
\hline Education & $0.517 * * *$ & 0.159 & $0.546 * * *$ & 0.159 \\
\hline Business Management & $1.738 * * *$ & 0.253 & $1.723 * * *$ & 0.253 \\
\hline \multicolumn{5}{|l|}{ Financial Support (Reference: Others) } \\
\hline Fellowship/grants/scholarships & $-0.745 * * *$ & 0.139 & $-0.739 * * *$ & 0.140 \\
\hline Research assistantship & $-0.471 * * *$ & 0.140 & $-0.486 * * *$ & 0.141 \\
\hline Teaching assistantship & -0.152 & 0.143 & -0.145 & 0.143 \\
\hline Foreign government & $-0.365 * * *$ & 0.159 & $-0.299 * * *$ & 0.162 \\
\hline Loans & -0.035 & 0.063 & 0.158 & 0.063 \\
\hline Research institutions (Ref: Doctoral institutions) & $0.298 * * *$ & 0.122 & $0.291 * * *$ & 0.123 \\
\hline \multicolumn{5}{|c|}{ Home Country Classification (Reference: High-Income) } \\
\hline Upper-middle-income & $-0.206 * * *$ & 0.065 & & \\
\hline Lower-middle-income & $-0.611 * * *$ & 0.068 & & \\
\hline Low-income & $-0.660 * * *$ & 0.174 & & \\
\hline \multicolumn{5}{|c|}{ Home Country Classification (Reference: Europe and Central Asia) } \\
\hline East Asia and Pacific & & & $0.575 * * *$ & 0.079 \\
\hline Latin America and the Caribbean & & & 0.195 & 0.108 \\
\hline Middle East and North Africa & & & $0.325 * * *$ & 0.106 \\
\hline North America & & & 0.013 & 0.140 \\
\hline South Asia & & & $-0.224 * * *$ & 0.091 \\
\hline Sub-Saharan Africa & & & 0.165 & 0.159 \\
\hline
\end{tabular}

Note $* \rho \leq 0.05 * * \rho \leq 0.01 * * * \rho \leq 0.001$

\section{Discussion and Conclusion}

To further address the research questions, Figures 1 and 2 present plots of predicted probabilities for interaction terms between region/home country wealth and source of support. All the predicted probabilities were statistically significant at the $\mathrm{p}<0.001$. Figure 2 and Table 4 (found in the Appendix) present predictions from the model for the probability of planning to work as a faculty member for the home country classifications with the various sources of financial support. Similarly, Figures 3-4 and Table 5 (found in the Appendix) present predicted probabilities for planning to work as a post-doctoral researcher for the various interactions between Home Country classification and Source of Support. The purpose of the plots is to show graphically whether the relationship between financial sources of support and post-graduation plans follows a similar pattern for international doctoral students.

The plots of predicted probabilities show that the interaction of research assistantships and students from low-income countries have the largest estimated effect on post-graduation plans to be faculty. The prediction for planning to work as a faculty member was highest among students from North America whose primary source of support were loans. Financial sources of support have a similar pattern of predicted probabilities amongst the international students as a group. This study contributes to the literature by empirically testing the relationship between different sources of funding and the post-graduation plans of international doctoral students. 
Additionally, the findings are relevant to scholars and policymakers who are interested in leveraging funding to increase the representation of students from poorer countries who pursue faculty or research careers.

This nuanced understanding of post-graduation plans among international $\mathrm{PhD}$ recipients provides important points of consideration. This research was limited by the self-report nature of the SED dataset and the collection of the data prior to graduation. Thus, the difference between intended and actual career plans are unknown. However, this examination provides several important implications and directions for future research. Institutions of higher education must understand the impact of funding on their $\mathrm{PhD}$ recipients' post-graduation career plans as they relate to employability. Additionally, it is important for institutions to consider the ways in which country of origin, financial support, and academic discipline intersect with post-graduation career plans in academia, government, and industry.

Future research could examine the $\mathrm{PhD}$ advisor relationship in addition to the factors already studied in this research and how they impact career plans. Future research could also use primary data to include the socioeconomic status of the student. This research is only able to capture the economic rating of the country and first-generation status. Additionally, more research is needed in understanding the motivations for pursuing postdoctoral training versus accepting a position in industry post-graduation, particularly as it relates to students from low-income countries and minority students amongst the international student population. In this regard, a qualitative research design could further investigate the underlying factors that go into their decision-making process. Graduate program directors may consider the types of funding awarded to international students and how they align with their career goals.

Figure 1.

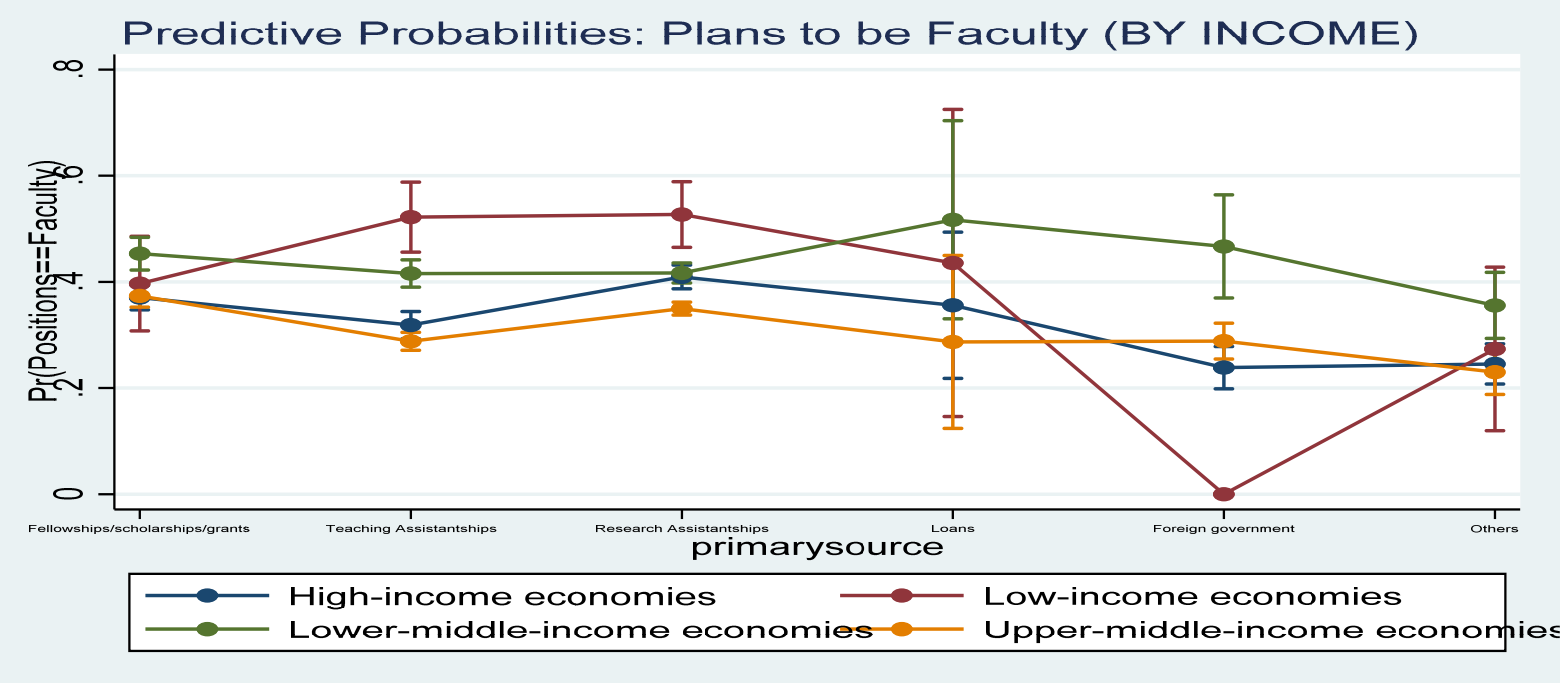

Figure 2.

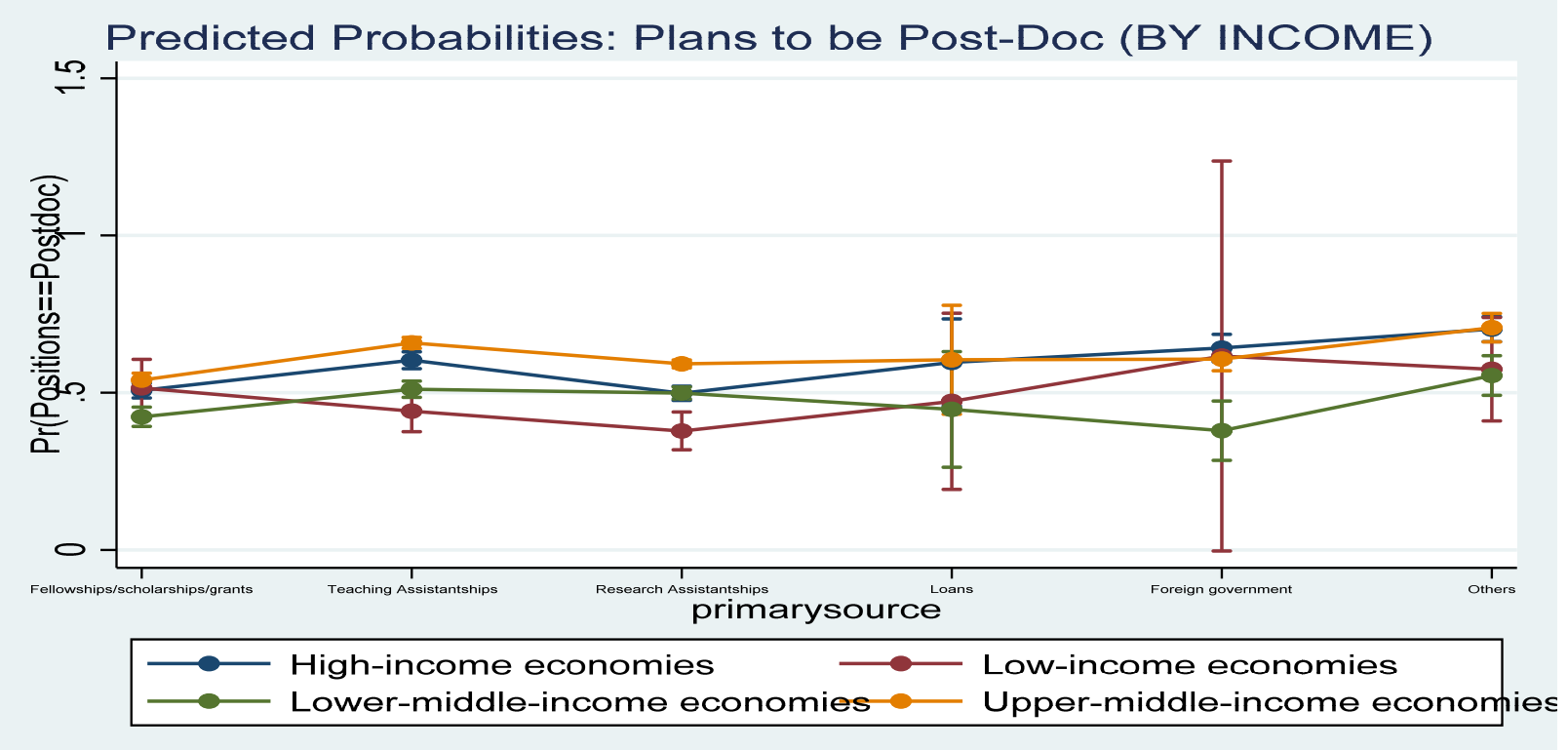


Figure 3.

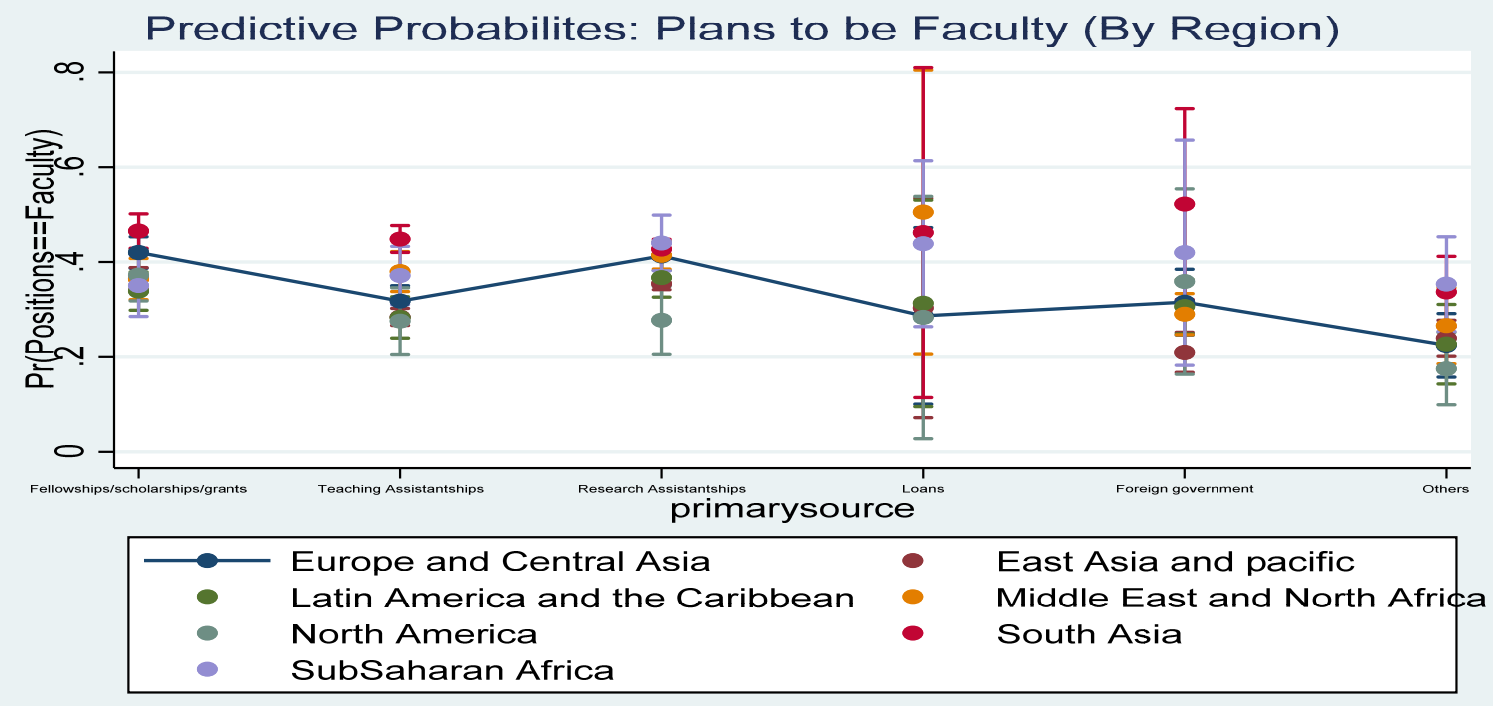

Figure 4.

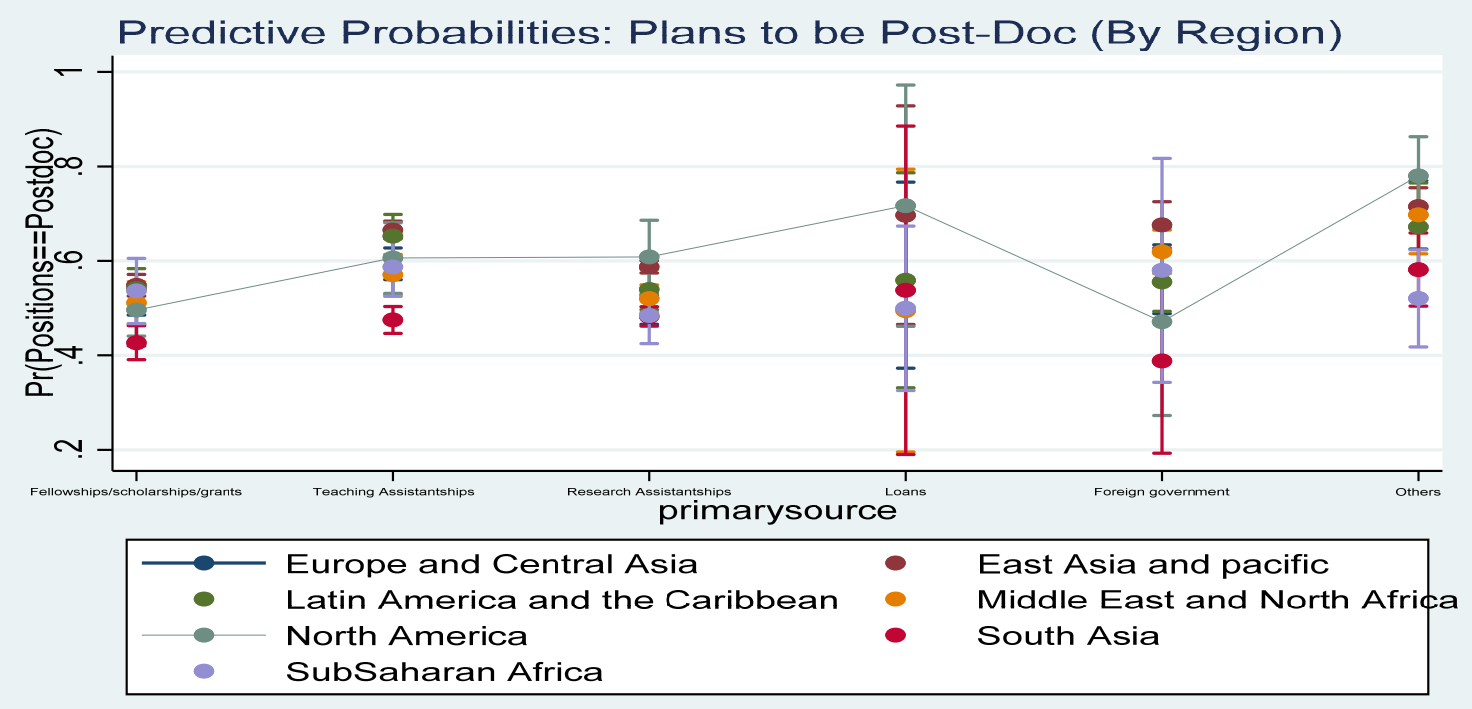

\section{References}

Agarwal, R., \& Sonka, S. (2010). Different strokes for different folks: University programs that enable diverse career choices of young scinetists. In G. D. Libecap, M. Thursby, \& S. Hoskinson (Eds.), Spanning boundaries and disciplines: University technology commercialization in the idea age (pp. 139-164). Emerald Group Publishing Limited.

Agbonlahor, O. (2019). The impact of financial aid factors and home country economic conditions on international doctoral students time-to-degree completion and labor market destination choices [Unpublished doctoral dissertation]. Central Michigan University.

Agbonlahor, O., \& Ampaw, F. (2021). Understanding country differences: Predicting the effect of financial and labor market conditions on international doctoral recipients first labor market destination. Journal of International Students, 11(2), 459-483. https://doi.org/10.32674/jis.v11i2.1420

Austin, A. E., \& McDaniels, M. (2006). Preparing the professoriate for the future: Graduate student socialization for faculty roles. In J. C. Smart (Ed.), Higher education: Handbook of theory and practice (Vol 21, pp. 397456). Springer Publishers. https://doi.org/10.1007/1-4020-4512-3_8

Becker, G. S. (1964). Human capital: A thereotical and empirical analysis, with special reference to education. Columbia University Press.

Bloch, C., Graversen, E. K., \& Pedersen, H. S. (2015). Researcher mobility and sector career choices among doctorate holders. Research Evaluation, 24, 171-180. 
Corcoran, M., \& Clark, S. M. (1984). Professional socialization and contemporray career attitudes of three faculty genartions. Research in Higher Education, 20(1), 131-153.

Cruz-Castro, L., \& Sanz-Menedez, L. (2005). The employment of PhDs in firms: Trajectories, mobility annd innovation. Research Evaluation, 14(1), 57-69.

Dongbin, K., \& Otts, C. (2010). The effect of loans on time-to-degree: Differences by race/ethnicity, field of study, and institutional characteristics. The Journal of Higher Education, 81(1), 1-32.

Ehrenberg, R. G., \& Marvos, P. G. (1995). Do doctoral students' financial support patterns affect their time-todegree and completion probabilities? The Journal of Human Resources, 3, 581-609.

Ehrenberg, R. G., Jakubson, G. H., Groen, J. A., So, E., \& Price, J. (2007). Inside the black box of doctoral education: What program charcteristics influence doctoral students' attrition and graduation probabilities? Educational Evaluation and Policy Analysis, 29(2), 134-150.

Ellis, E. M. (2001). The impact of race and gender on graduate school socialization, satisfaction with doctoral study, and commitment to degree completion. The Western Journal of Black Studies, 25(1), 30-45.

Fernandez, F. (2019). What's money got to do with it? An examination of the relationships between sources of financial support and the post-graduation plans of Latina and Latino doctoral students in the social sciences. The Review of Higher Education, 43(1), 143-168.

Ferrer de Valero, Y. (2001). Departmental factors affecting time-to-degree and completion rates of doctoral students at one land-grant research institution. The Journal of Higher Education, 72(3), 341-367.

Garson, D. (2016). Logistic regression: Binary and multinomial, 2016 edition. Statistical Associates Publishers.

Gemme, B., \& Gingras, Y. (2012). Academic careers for graduate students: A strong attractor in a change environment. Higher Education, 63(6), 667-683.

Gibbs, K. D., McGready, J., Bennett, J. C., \& Griffin, K. (2014). Biomedical science PhD career interest patterns by race/ethnicity and gender. PLOS ONE, 9(12), 1-18.

Gluck, M. E., Blumenthal, D., \& Stoto, M. A. (1987). University-industry relationships in the life sciences: Implications for students and post-doctoral fellows. Research Policy, 16, 327-336.

Ku, H.-Y., Lahman, M. K., Yeh, H.-T., \& Cheng, Y.-C. (2008). Into the academy: Preparing and menoring international doctoral students. Education Technology Research Development, 56, 365-377.

Mangematin, V. (2000). PhD job market: Professional trajectories and incentives during the PhD. Research Policy, 29(1), 741-756.

Patrick, A., Borrego, M., \& Riegle-Crumb, M. (2017). Post-graduation plans of undergraduate BME students: Gender, self-efficacy, value, and identity beliefs. Annuals of Biomedical Engineering, 49(5), 1275-1287.

Pederson, H. S. (2015). Empirical essays on the labor market outcomes of PhD graduates [Unpublished doctoral dissertation]. Aarhus University, Denmark.

Roach, M., \& Sauermann, H. (2017). The declining interest in an academic career. PLoS ONE, 12(9), 1-12.

The World Bank. (2017). World Bank Country and Lending Groups. Retrieved from Country Classification: https://datahelpdesk.worldbank.org/knowledgebase/articles/906519-world-bank-country-and-lendinggroups

Thune, T. (2009). Doctoral students on the university-industry interface: A review of the literature. Higher Education, 58(1), 637-651.

Ugwu, D., \& Adamuti-Trache, M. (2017). Post-graduation plans of international science and engineering doctoral students attending U.S. universities. Journal of International Students, 7(1), 1-21.

\section{Appendix}

TABLE 4.

PREDICTED PROBABILITIES FOR PLANS TO BE FACULTY FOR HOME COUNTRY CLASSIFICATION*FINANCIALSUPPORT, 2010-2015.

\begin{tabular}{lcc}
\hline Financial support\#Income or Region of Home Country & Margin & Std. Err. \\
\hline Primarysource\#BYINCOME & $0.370^{* * *}$ & 0.012 \\
Fellowship\#High-income & $0.374^{* * *}$ & 0.011 \\
Fellowship\#Upper-middle-income & $0.453^{* * *}$ & 0.016 \\
Fellowship\#Lower-middle-income & $0.397^{* * *}$ & 0.045 \\
Fellowship\#Low-income & $0.319^{* * *}$ & 0.013 \\
Teaching assistantship\#High-income & $0.288^{* * *}$ & 0.009 \\
Teaching assistantship\#Upper-middle-income & $0.416^{* * *}$ & 0.013 \\
Teaching assistantship\#Lower-middle-income & $0.622^{* * *}$ & 0.034 \\
Teaching assistantship\#Low-income & $0.409^{* * *}$ & 0.011 \\
Research assistantships\#High-income & $0.350^{* * *}$ & 0.006 \\
Research assistantships\#Upper-middle-income & $0.417^{* * *}$ & 0.010
\end{tabular}




\begin{tabular}{|c|c|c|}
\hline Financial support\#Income or Region of Home Country & Margin & Std. Err. \\
\hline Research assistantships\#Low-income & $0.627 * * *$ & 0.032 \\
\hline Loans\#High-income & $0.356^{* * *}$ & 0.070 \\
\hline Loans\#Upper-middle-income & 0.287 & 0.083 \\
\hline Loans\#Lower-middle-income & $0.517 * * *$ & 0.095 \\
\hline Loans\#Low-income & 0.436 & 0.148 \\
\hline Foreign government\#High-income & $0.238 * * *$ & 0.020 \\
\hline Foreign government\#Upper-middle-income & $0.288^{* * *}$ & 0.017 \\
\hline Foreign government\#Lower-middle-income & $0.467 * * *$ & 0.050 \\
\hline Foreign government\#Low-income & 0.000 & 0.000 \\
\hline Others\#High-income & $0.246^{* * *}$ & 0.019 \\
\hline Others\#Upper-middle-income & $0.230 * * *$ & 0.021 \\
\hline Others\#Lower-middle-income & $0.356 * * *$ & 0.032 \\
\hline Others\#Low-income economies & $0.274 * * *$ & 0.079 \\
\hline \multicolumn{3}{|l|}{ Primarysource\#BYREGION } \\
\hline Fellowships\#Europe and Central Asia & $0.420 * * *$ & 0.017 \\
\hline Fellowships\#East Asia and Pacific & $0.366^{* * *}$ & 0.011 \\
\hline Fellowships\#Latin America and the Caribbean & $0.339 * * *$ & 0.021 \\
\hline Fellowships\#Middle East and North Africa & $0.364 * * *$ & 0.022 \\
\hline Fellowships\#North America & $0.372 * * *$ & 0.028 \\
\hline Fellowships\#South Asia & $0.465 * * *$ & 0.018 \\
\hline Fellowships\#SubSaharan Africa & $0.351 * * *$ & 0.033 \\
\hline Teaching assistantships\#Europe and Central Asia & $0.318^{* * *}$ & 0.017 \\
\hline Teaching assistantships\#East Asia and Pacific & $0.284 * * *$ & 0.009 \\
\hline Teaching assistantships\#Latin America and the Caribbean & $0.283 * * *$ & 0.022 \\
\hline Teaching assistantships\#Middle East and North Africa & $0.380^{* * *}$ & 0.022 \\
\hline Teaching assistantships\#North America & $0.275^{* * *}$ & 0.036 \\
\hline Teaching assistantships\#South Asia & $0.449 * * *$ & 0.015 \\
\hline Teaching assistantships\#SubSaharan Africa & $0.371 * * *$ & 0.031 \\
\hline Research assistantships\#Europe and Central Asia & $0.413 * * *$ & 0.016 \\
\hline Research assistantships\#East Asia and Pacific & $0.354 * * *$ & 0.006 \\
\hline Research assistantships\#Latin America and the Caribbean & $0.367 * * *$ & 0.021 \\
\hline Research assistantships\#Middle East and North Africa & $0.414 * * *$ & 0.015 \\
\hline Research assistantships\#North America & $0.277 * * *$ & 0.037 \\
\hline Research assistantships\#South Asia & $0.428 * * *$ & 0.010 \\
\hline Research assistantships\#SubSaharan Africa & $0.440 * * *$ & 0.030 \\
\hline Loans\#Europe and Central Asia & 0.287 & 0.095 \\
\hline Loans\#East Asia and Pacific & 0.303 & 0.118 \\
\hline Loans\#Latin America and the Caribbean & 0.313 & 0.111 \\
\hline Loans\#Middle East and North Africa & 0.505 & 0.153 \\
\hline Loans\#North America & 0.283 & 0.130 \\
\hline Loans\#South Asia & $0.462 * * *$ & 0.177 \\
\hline Loans\#SubSaharan Africa & $0.439 * * *$ & 0.089 \\
\hline Foreign government\#Europe and Central Asia & $0.315^{* * *}$ & 0.035 \\
\hline Foreign government\#East Asia and Pacific & $0.209 * * *$ & 0.021 \\
\hline Foreign government\#Latin America and the Caribbean & $0.306^{* * *}$ & 0.029 \\
\hline Foreign government\#Middle East and North Africa & $0.290 * * *$ & 0.022 \\
\hline Foreign government\#North America & $0.359 * * *$ & 0.100 \\
\hline Foreign government\#South Asia & $0.522 * * *$ & 0.103 \\
\hline Foreign government\#SubSaharan Africa & 0.420 & 0.121 \\
\hline
\end{tabular}

Note $* * * \rho<0.001$ 
TABLE 5.

PREDICTED PROBABILITY FOR PLANS TO BE A POSTDOCTORAL RESEARCHER FOR HOME COUNTRY CLASSIFICATION*FINANCIALSUPPORT, 2010-2015.

\begin{tabular}{|c|c|c|}
\hline Financial support\#Income or Region of Home Country & Margin & Std. Err. \\
\hline \multicolumn{3}{|l|}{ Primarysource\#BYINCOME } \\
\hline Fellowship\#High-income & $0.507 * * *$ & 0.012 \\
\hline Fellowship\#Upper-middle-income & $0.540 * * *$ & 0.011 \\
\hline Fellowship\#Lower-middle-income & $0.423 * * *$ & 0.016 \\
\hline Fellowship\#Low-income & $0.515 * * *$ & 0.046 \\
\hline Teaching assistantship\#High-income & $0.603 * * *$ & 0.014 \\
\hline Teaching assistantship\#Upper-middle-income & $0.659 * * *$ & 0.009 \\
\hline Teaching assistantship\#Lower-middle-income & $0.511 * * *$ & 0.013 \\
\hline Teaching assistantship\#Low-income & $0.441 * * *$ & 0.033 \\
\hline Research assistantships\#High-income & $0.498 * * *$ & 0.012 \\
\hline Research assistantships\#Upper-middle-income & $0.592 * * *$ & 0.006 \\
\hline Research assistantships\#Lower-middle-income & $0.499 * * *$ & 0.010 \\
\hline Research assistantships\#Low-income & $0.378 * * *$ & 0.031 \\
\hline Loans\#High-income & $0.596 * * *$ & 0.071 \\
\hline Loans\#Upper-middle-income & $0.605 * * *$ & 0.088 \\
\hline Loans\#Lower-middle-income & $0.447 * * *$ & 0.094 \\
\hline Loans\#Low-income & 0.472 & 0.143 \\
\hline Foreign government\#High-income & $0.642 * * *$ & 0.022 \\
\hline Foreign government\#Upper-middle-income & $0.607 * * *$ & 0.019 \\
\hline Foreign government\#Lower-middle-income & $0.379 * * *$ & 0.048 \\
\hline Foreign government\#Low-income & 0.617 & 0.316 \\
\hline Others\#High-income & $0.702 * * *$ & 0.020 \\
\hline Others\#Upper-middle-income & $0.707 * * *$ & 0.023 \\
\hline Others\#Lower-middle-income & $0.555^{* * *}$ & 0.032 \\
\hline Others\#Low-income & $0.575 * * *$ & 0.084 \\
\hline \multicolumn{3}{|l|}{ Primarysource\#BYREGION } \\
\hline Fellowships\#Europe and Central Asia & $0.453 * * *$ & 0.017 \\
\hline Fellowships\#East Asia and Pacific & $0.548 * * *$ & 0.012 \\
\hline Fellowships\#Latin America and the Caribbean & $0.542 * * *$ & 0.022 \\
\hline Fellowships\#Middle East and North Africa & $0.511 * * *$ & 0.023 \\
\hline Fellowships\#North America & $0.496 * * *$ & 0.028 \\
\hline Fellowships\#South Asia & $0.427 * * *$ & 0.018 \\
\hline Fellowships\#SubSaharan Africa & $0.536^{* * *}$ & 0.035 \\
\hline Teaching assistantships\#Europe and Central Asia & $0.594 * * *$ & 0.017 \\
\hline Teaching assistantships\#East Asia and pacific & $0.665 * * *$ & 0.010 \\
\hline Teaching assistantships\#Latin America and the Caribbean & $0.653 * * *$ & 0.023 \\
\hline Teaching assistantships\#Middle East and North Africa & $0.571 * * *$ & 0.022 \\
\hline Teaching assistantships\#North America & $0.606^{* * *}$ & 0.038 \\
\hline Teaching assistantships\#South Asia & $0.475 * * *$ & 0.015 \\
\hline Teaching assistantships\#SubSaharan Africa & $0.587 * * *$ & 0.032 \\
\hline Research assistantships\#Europe and Central Asia & $0.497 * * *$ & 0.016 \\
\hline Research assistantships\#East Asia and pacific & $0.588 * * *$ & 0.007 \\
\hline Research assistantships\#Latin America and the Caribbean & $0.540 * * *$ & 0.022 \\
\hline Research assistantships\#Middle East and North Africa & $0.520 * * *$ & 0.015 \\
\hline Research assistantships\#North America & $0.609 * * *$ & 0.040 \\
\hline Research assistantships\#South Asia & $0.482 * * *$ & 0.011 \\
\hline Research assistantships\#SubSaharan Africa & $0.484 * * *$ & 0.030 \\
\hline Loans\#Europe and Central Asia & $0.570 * * *$ & 0.101 \\
\hline Loans\#East Asia and Pacific & $0.697 * * *$ & 0.118 \\
\hline Loans\#Latin America and the Caribbean & $0.559 * * *$ & 0.116 \\
\hline Loans\#Middle East and North Africa & 0.495 & 0.153 \\
\hline Loans\#North America & $0.717 * * *$ & 0.130 \\
\hline Loans\#South Asia & 0.538 & 0.177 \\
\hline Loans\#SubSaharan Africa & $0.500 * * *$ & 0.089 \\
\hline Foreign government\#Europe and Central Asia & $0.561 * * *$ & 0.037 \\
\hline
\end{tabular}




\begin{tabular}{lll}
\hline Financial support\#Income or Region of Home Country & Margin & Std. Err. \\
\hline Foreign government\#East Asia and Pacific & $0.676^{* * *}$ & 0.025 \\
Foreign government\#Latin America and the Caribbean & $0.556^{* * *}$ & 0.032 \\
Foreign government\#Middle East and North Africa & $0.619^{* * *}$ & 0.024 \\
Foreign government\#North America & $0.471^{* * *}$ & 0.101 \\
Foreign government\#South Asia & $0.388^{* * *}$ & 0.100 \\
Foreign government\#SubSaharan Africa & $0.580^{* * *}$ & 0.121 \\
\hline Note $* * * \rho<0.001$ & &
\end{tabular}

Note $* * * \rho<0.001$ 